Volume 6 Issue 2, June 2019

\title{
Legal Analysis on Status as A Co-Defendant Notary in Dispute of Gather Treasure (Case Study in The Court of Ungaran District No: 105 / Pdt.G / 2016 / PN.Unr)
}

\author{
Rudy Iskandar Ichlas ${ }^{1}$ and Akhmad Khisni ${ }^{2}$
}

Abstract. Authentic Deed is not solely determined by the law but must also be made before a public official even though the parties have signed. Pernasalahan formulation of this research: 1 . How plaintiff legal reasons related to the notary as a co-defendant in the decision number 105 / Rev. G / 2016 / PN. Unr ?, 2. What legal consequences for the Notary as a co-defendant in the decision number 105 / Rev. G / 2016 / PN. Unr. In conclusion: 1). Position Anief Ratnawati, SH, Notary / PPAT in Ungaran as Co-Defendant extremely detrimental due to the lack of legal certainty as Co-Defendant and One goal (error in persona). Hence proved their obscuur libel and Error In Persona judge shall include in its decision to declare the judgment can not receive (NO: Niet ontvankelijk verklaard) lawsuit plaintiffs, 2). Anief Ratnawati, $\mathrm{SH}$. as a Notary Public who is drawn into the dispute be imprecise Co-Defendant not authorized in terms of time (Onbevoegdheid ratione Temporis) and violates the principle of legality and the principles of civil law as private law. On the other hand the plaintiff proved to be an inheritance dispute within the competence of religious courts

Keywords: Legal Analysis; Notary; Co-defendant; Dispute; Gather Treasure.

\section{Introduction}

Notary deed prescribed by law as legal certainty ${ }^{3}$ so legally quality is unquestionable. Another case, if the letter outside the provisions of the legislation it is necessary legitimacy of the authorities to be authentic.

Authentic Deed is not solely determined by the law but must also be made before a public official even though the parties have signed. That the Notary as a public official is in harmony with the provisions of Article 1 paragraph 1 of Act No. 2 of 2014 on the Amendment of Act No. 30 of 2004 concerning Notary, where it is stated: "Notary is a public official who is authorized to make the deed authentic and have other authorities referred to in this Act or under any other laws. "

In the case of property dispute Gono-gini, the legal practitioners in this case Advocate or the attorney would review the procedure as a benchmark of principal principle thinking ${ }^{4}$, If found his legal loophole then this is the potential to issue legally. Because the problem is a formal legal procedure is by itself very closely linked to the civil law that are looking for formal correctness.

Related legal loopholes certificate issuance form of transitional grant land rights from property Gono gini by Notary been disputed in the District Court Ungaran, Central Java Province. The facts contained in the decision of the District Court Ungaran with No. 105 / Pdt. G / 2016 / PN. Unr. Where in this case, the plaintiffs include two people as the Co-Defendant Notary.

1 Lecturer of Faculty of Law, University of Muhammadiyah Kendari, email: rudyfhumk@gmail.com

${ }^{2}$ Lecturer of Faculty of Law UNISSULA

3 Muhammad Ishom, 2007,Legal Drafting,Setara Press,Malang, p.50

${ }^{4}$ Mundiri, 2014, Logika, RajaGrafindo Persada, Jakrta, p.11 
Notary became the co-defendant in a person's engagement is also influenced interpretation of the deed of agreement Notary product concerned. Since the problem of interpretation of the agreement, including one important thing in any agreement, either at the time of making the agreement and on its application in the future. ${ }^{5}$

Understandable then, status as Co-Defendant to the Notary argued by the plaintiff, because no legal responsibility for publishing Notary deed grants contained in case No. 105 / Pdt. G / 2016 / PN. Unr it. Because it has the legal responsibility for such aktanya, it makes sense to be disputed by those who feel aggrieved by the publication of the grant deed.

Notary is legally liable to the deed he made also the order of Article 65 of Act No. 2 of 2014 on the Amendment of Act No. 30 of 2004 concerning Notary, namely: "Notaries, Notary Substitute, and Acting Notary responsible for any deed that is made despite the Protocol Notary has been assigned or transferred to the storage Notary Protocol."

As a result of the transition grant certificate issuance of the land rights of property Gono gini in case No. 105 / Pdt. G / 2016 / PN. Unr, it is interesting to study scientifically. Although the ruling in this case the judge ruled the District Court Ungaran not authorized to examine, decide and resolve this matter but its jurisdiction, at least the charge material from the claimant that puts the notary as the Co-Defendant attract the interest of researchers.

From the background above, lifted the title: "Analysis of the Status Law Against Notary As Co-Defendant In Dispute of Gather Treasure ( Case Study in The Court of Ungaran District No: 105 / Pdt.G / 2016 / PN.Unr). The formulation of the problems presented by the above description is: How plaintiff legal reasons related to the notary as a codefendant in the decision number 105 / Rev. G / 2016 / PN. Unr? How the legal consequences for the Notary as a co-defendant in the decision number 105 / Rev. G / 2016 / PN. Unr?

\section{Research methods}

In obtaining the data and information on this study used a method socio legal research approach. This method is a scientific method / scientific because it is in compliance with scientific principles, namely concrete / empirical, objective, measurable, rational and systematic. Methods of data collection, carried out literature studies and interviews with a number of parties. The research was done by performing a search and study the library materials needed in respect of legal issues that have been formulated. And supported also by purposive random sampling technique. Data analysis methods, using the method of normative analysis. This method is a way of interpreting the results of research based material legal norms, legal sense, rule of law, and legal theory which is closely related to the problem. Legal norms are needed as a major premise which is then correlated with a number of relevant facts (legal fact) that serves as the minor premise. By going through the process will be concluded syllogism (conclution) to the problems previously set.

\section{Results And Discussion}

\subsection{Reason Related Plaintiff Law Notaries As a Co-Defendant In Decision No. 105 / Pdt. G / 2016 / PN. Unr.}

\footnotetext{
${ }^{5}$ Yudha Bhakti Ardhiwisastra, 2012, Penafsiran Hukum Dan Konstruksi Hukum, Cetakan ke -3, Alumni,Bandung, p.21
} 
Volume 6 Issue 2, June 2019

Based posita plaintiff can be seen that the two Notary / PPAT respectively, Sri Rachma Chandrawati, $\mathrm{SH}$ and Anief Ratnawati, SH, being the Co-Defendant in Case Number: 105 / Rev. G / 2016 / PN. Unr, is. The reason for the plaintiffs can be reviewed based on the following matters:

- Status Inconsistency Co-Defendants and Lawsuit Libel obscuur

Known then, Sri Rachma Chandrawati, SH as a Notary Public who publishes Grant Deed No. 183 / HIB / UNR / VI / 1997, moved to Jakarta for the next Notary / PPAT Hardiyanti Husodo, SH appointed as a Notary successor and the last forwarded by Anief Ratnawati, SH, Notary / PPAT in Ungaran as Notary successor, then the claimant is declared as Co-Defendant II (vide, posita claimant numbers: 12)

Posita observed then that the claimant's arguments ketiksesuaian between one another. Ie between posita number 12 to number 21. Where stated "Anief Ratnawati, SH, Notary / PPAT in Ungaran as Notary successor / Co-Defendant II" (vide, posita claimant numbers: 12) while posita number 21 stated that "Anief Ratnawati, SH , Notary / PPAT in Ungaran as Notary successor / Co-Defendant III. " Furthermore, the legal status of Anief Ratnawati, SH, Notary / PPAT in Ungaran as Notary successor / Co-Defendant III in posita numbers 20, 21 and 24 then again become ambiguous when compared posita plaintiff number 17 . In posita number 17 it is stated that Co-Defendant III Village Head Nyatnyono is not the case Anief Ratnawati, SH, as in posita numbers 20, 21 and 24 referred to.

Not in conformity with the above explanation as then formally proven no fatal errors on the plaintiff. That is, the legal status of the plaintiff argued against Anief Ratnawati, $\mathrm{SH}$, be misleading, vague or inaccurate (obscuur libe). Inconsistency codefendant's status arbitrary actions are theoretically not appropriate justice. ${ }^{6}$

Supposedly also, in consideration of the judge or the defendant's exception. This is due, which is obscuur libel lawsuit also lead plaintiff declared unacceptable (Niet ontvankelijk verklaard) by assembly

- Notary Co-Defendants Error In Persona

Posita overall plaintiff who puts Anief Ratnawati, SH, Notary / PPAT as the defendant in accordance with Article 65 of Act No. 2 of 2014 on the Amendment of Act No. 30 of 2004 concerning Notary, namely: "Notaries, Notary Substitute, and Acting Notary responsible for any deed that is made despite the Protocol Notary has been assigned or transferred to the storage Notary Protocol."

Legal protection against Ratnawati Anief in accordance with Article 65 of Act No. 2 of 2014 should be interpreted as the depositary of the Protocol Notary Deed in respect of Grant No. 183 / HIB / UNR / VI / 1997 which is actually the product of Notary Sri Rachma Chandrawati, SH .. As the holder Protol Anief Ratnawati should deviate and maintain a state archive. ${ }^{7}$

However, the position of Article 65 of Act No. 2 of 2014 was not a retroactive application of the law. Because of its position in the dispute as the depositary of the Protocol is not the issuing party Deed of Grant No. 183 / HIB / UNR / VI / 1997. Because Anief Ratnawati, SH, Notary / PPAT in Ungaran replace Notary / PPAT Hardiyanti HUSODO, SH previously replace Sri Rachma Chandrawati, SH. And because of the dispute occurred in 2016 as stated in the decision number Anief position Ratnawati, SH, Notary / PPAT in Ungaran bound by Act No. 30 of 2014.

\footnotetext{
${ }^{6}$ Salim HS dan Erlies Septiana Nurbani,2014, Penerapan Teori Hukum Pada Penelitian Disertasi Dan Tesis, RajaGrafindo Persada, Jakarta, p.25.

7 Santia Dewu dan R.M. Fauwas Diradja,2011, Panduan Teori\&Praktik Notaris, Pustaka Yustisia, Yogyakarta, p.88
} 
Based described above then Anief Ratnawati, SH, Notary / PPAT in Ungaran as CoDefendant in case number: 105 / Rev. G / 2016 / PN. Unr, is legally incorrect and misplaced because de yure contrary to Article 65 of Act No. 2 of 2014 on the Amendment of Act No. 30 Of 2004 on Notary. Legal liability is still attached to the Sri Rachma Chandrawati, SH., As a Notary Public who publishes the Deed of Grant No. 183 / HIB / UNR / VI / 1997, which became part of the object of the dispute.

Therefore, based on these descriptions then Anief Ratnawati, SH, Notary / PPAT in Ungaran as Co-Defendant in case number: 105 / Rev. G / 2016 / PN. Unr., Is misplaced. The lawsuit misdirected because the judge should also declare in the verdict that the plaintiff Error In Persona.

\subsection{Effects Related Plaintiff Notary As Co-Defendant In Decision No. 105 / Pdt. G / 2016 / PN. Unr.}

With regard to the plaintiff posita legal consequences for the Notary as Co-Defendant in the decision on case number 105 / Rev. G / 2016 / PN. Unr, can be evaluated based on the following:

- Notary Onbevoegdheid ratione Temporis

Delegation of notary protocols received by Anief Ratnawati, SH. as Notary / PPAT in Ungaran stems from the authority in Sri Rachma Chandrawati, SH. However, in terms of legal consequences issuance Grant Deed No. 183 / HIB / UNR / VI / 1997, in tempus delicti (in terms of time of the event) is still a tangungjawab Sri Rachma Chandrawati, $\mathrm{SH}$. This is understandable due to the transfer of a notary protocol long after the issuance of the Deed of Grant No. 183 / HIB / UNR / VI / 1997 referred to. Based on the principle of legality authority should not be retroactive. As a recognized authority plaintiff Anief Ratnawati, SH., In case No. 105 / Pdt. G / 2016 / PN. Unr. Moreover, the case in question is contrary to the civil case on personal responsibility.

With the above description it is not right if Anief Ratnawati, SH. as Notary / PPAT in Ungaran as Co-Defendant in Case Number: 105 / Rev. G / 2016 / PN. Unr., Because it violates the principle of legality and the principles of civil law as private law. Anief Ratnawati, SH., In theory as public officials categorized based on its legality Onbevoegdheid ratione Temporis (not authorized in terms of time) of the Deed of Grant No. 183 / HIB / UNR / VI / 1997 referred to.

- The principle of Lex posterior derogat legi Priori and Interests Other party Other legal consequences, if the terms of the legal principle of Lex posterior derogat legi Priori and the interests of the other party can be assessed by the plaintiff posita number 17 where in it is stated as follows: "That act of the village chief Nyatnyono / Co-Defendant III by creating and issuing the Certificate of Heritage No. 06 / W / 1984 on the Moon in July 1984 was an unlawful act; "

If proven the existence of an unlawful act it is evident there is also a carelessness Sri Rachma Chandrawati, SH Notary / PPAT in Ungaran / cq II Co-Defendant in issuing the Grant Deed No. 183 / HIB / UNR / VI / 1997. In a deed, a Notary is not solely to consider the interests of the parties facing him. Other parties that it is possible to be harmed due to certificate issuance should be considered. However, because the product Notary Sri Rachma Chandrawati, SH, occurred in 1997, it is not bound by UUJN based on the legal principle of Lex posterior derogat legi Priori (the 
new regulations override the old rules). According to Hart $^{8}$, Protection and the legal minimum benefits do not always reach all sides.

- Justice competence

Based Case Number: 105 / Rev. G / 2016 / PN. Unr., It is known that the plaintiff caused the emergence of one of the seven children of the testator (Drajad Hariadi / Defendant III) master disputed that are based on the Certificate of heritage created by the Village Head Nyatnyono No.06 / W / 1984 (vide posita no.10), which later became the basis of the issuance of ownership certificate on behalf of the disputed Drajad Hariadi / Defendant III. Furthermore, granting the disputed Drajat Hariadi to Kun Kadarsih (Defendant i) the grant deed No. 183 / HIB / UNR / VI / 1997 dated June 14, 1997, drawn up before Sri Rachma Chandrawati, SH Notary / PPAT in Ungaran / cq Co-Defendant II;

Grant Deed No. 183 / HIB / UNR / VI / 1997 dated June 14, 1997 with Sri Rachma Chandrawati, SH Notary / PPAT in Ungaran / cq Co-Defendant II, clearly an inheritance dispute. Because of this deed does not necessarily rise but based on the property certificate on behalf of Drajad Hariadi / Defendant III where previously processed by the Certificate of heritage created by the Village Head Nyatnyono No.06 / W / 1984.

Thus, the grant deed No. 183 / HIB / UNR / VI / 1997 dated June 14, 1997 with Sri Rachma Chandrawati, SH Notary / PPAT in Ungaran / cq Co-Defendant II, is part of a disputed inheritance. This is because by observing the disputed ownership transition process supported by the Certificate of heritage created by the Village Head Nyatnyono No.06 / W / 1984, it is appropriate that a dispute of an inheritance dispute not dispute the right. If the inheritance dispute it should be understood then that the parties to an heir is a Muslim of course disputes that occur must be resolved in the Religious Court. The plaintiff is not relefan legally within the competence of general courts because it could not be subjected to the law. ${ }^{9}$

\section{Closing}

\subsection{Conclusion}

Based on the research that has been presented at the conclusion herewith presented is as follows:

- Position Anief Ratnawati, SH, Notary / PPAT in Ungaran as Co-Defendant extremely detrimental due to the lack of legal certainty as Co-Defendant and One goal (error in persona).

Hence proved their obscuur libel and Error In Persona judge shall include in its decision to declare the judgment can not receive (NO: Niet ontvankelijk verklaard) lawsuit plaintiffs.

- Anief Ratnawati, SH. as a Notary Public who is drawn into the dispute be imprecise Co-Defendant not authorized in terms of time (Onbevoegdheid ratione Temporis) and violates the principle of legality and the principles of civil law as private law. On the other hand the plaintiff proved to be an inheritance dispute within the competence of religious courts.

\footnotetext{
${ }^{8}$ H.L.A. Hart, 2016, Konsep Hukum,Sectakan ke VIII, Nusa Media, Bandung, p.309

9 Abintoro Prakoso,2016, Penemuan Hukum: Sistem, Metode dan Aliran dalam Menemukan Hukum, LaksBang PRESSindo, Yogyakarta, p.160
} 


\subsection{Suggestion}

With the conclusion has been reached then the advice that can be given regarding the following matters:

- It takes a reconstruction law so that there is a new legal norm set the Notary shall issue a deed more thoroughly and carefully. Therefore, UUJN current is converted and added the principle or principles of rigor and prudence.

- Because the judge's ruling states within the competence of the religious courts should further based on the conclusions of this study it is necessary to fix the complaint with respect to: The consistency of the legal status of co-defendant, Tempus delicti, Principle Lex posterior derogat legi Priori, judicial competence

\section{Bibliography}

\section{Books}

[1] Abintoro Prakoso, 2016, Penemuan Hukum: Sistem, Metode dan Aliran dalam Menemukan Hukum, LaksBang PRESSindo, Yogyakarta

[2] H.L.A. Hart, 2016,Konsep Hukum, Sectakan ke VIII, Nusa Media, Bandung

[3] Muhammad Ishom, 2007, Legal Drafting, Setara Press, Malang .

[4] Mundiri, 2014, Logika, RajaGrafindo Persada, Jakrta.

[5] Yudha Bhakti Ardhiwisastra, 2012,Penafsiran Hukum Dan Konstruksi Hukum, Cetakan ke -3, Alumni, Bandung.

[6] Salim HS dan Erlies Septiana Nurbani, 2014, Penerapan Teori Hukum Pada Penelitian Disertasi Dan Tesis, RajaGrafindo Persada, Jakarta.

[7] Santia Dewu dan R.M. Fauwas Diradja, 2011, Panduan Teori \& Praktik Notaris, Pustaka Yustisia, Yogyakarta.

\section{Legislation}

[1] Constitution of the Republic of Indonesia of 1945

[2] Law of the Republic of Indonesia Number 30 of 2004 concerning Notary

[3] Act No. 49 Of 2009 regarding the Second Amendment Act No. 2 of 1986 on the General Court

[4] Act No. 2 of 2014 On the Amendment of Act No. 30 of 2004 concerning Notary 